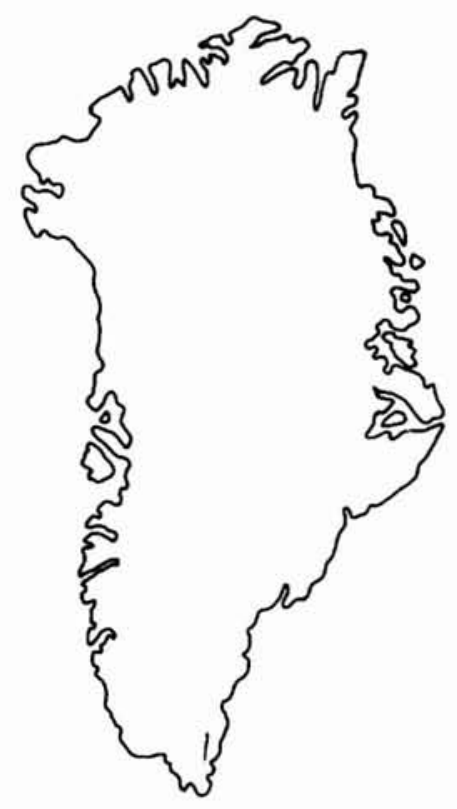

\title{
Mesozoic and Cenozoic history of the Wandel Sea Basin area, North Greenland
}

\author{
Eckart Håkansson, Claus Heinberg and \\ Lars Stemmerik
}

\begin{abstract}
Mesozoic deposition in North Greenland is characterised largely by increasing complexity in the configuration of sub-basins developed in response to the major tectonic events in the Wandel Hav Strike-Slip Mobile Belt.

While erosional remnants of Lower and Middle Triassic marine deposits are now confined to a very restricted area, Upper Jurassic - Lower Cretaceous marine to terrestrial deposition took place in two distinct sub-basins resulting from Jurassic left-lateral displacement in the Ingeborg Event. Variable marine and terrestrial Upper Cretaceous strata are restricted to local pull-apart basins formed in the right-lateral mid-Cretaceous Kilen Event; deposition in these basins was everywhere terminated in the continuously right-lateral transpressional movements of the Kronprins Christian Land Orogeny. Compression ceased around the Cretaceous-Tertiary boundary, and a post-orogenic terrestrial sequence of probable Paleocene age is disturbed only by extensional structures.
\end{abstract}

E. H. \& C. H., Institute of Historical Geology and Palaeontology, University of Copenhagen, Øster Voldgade 10, DK-1350 Copenhagen K, Denmark.

L. S., Geological Survey of Greenland, Øster Voldgade 10, DK-1350 Copenhagen K, Denmark.

The history of exploration of Mesozoic and Cenozoic rocks in North Greenland is brief, even for this remote part of the world. The first post-Palaeozoic fossils were collected from the dark (Cretaceous) sandstones at Nakkehoved on the north coast of Kronprins Christian Land by Eigil Nielsen of the Danish Northeast Greenland Expedition in 1939 (Nielsen, 1941). Ten years later J. C. Troelsen of the Danish Peary Land Expedition (1947-50) added strata of definite Triassic age to the very short list of post-Palaeozoic occurrences, based on localities in eastern Peary Land where younger plantbearing (Cretaceous) strata were also found (Troelsen, 1950; Kummel, 1953). Reports of Lower Tertiary and Middle Jurassic strata, which were largely unsubstantiated or subsequently shown to be erroneous, were included by Dawes (1976) in the first synthesis of the entire Wandel Sea Basin history. However, knowledge concerning the distribution and history of the post-Palaeozoic strata did not attain a level sufficient to allow more precise speculation about the Mesozoic and Cenozoic development in this crucial corner of the North American continental plate until large scale investigations were initiated during the North Greenland Project of the Geological Survey of Greenland (1978-80); later work has also been supported by the Carlsberg Foundation, Copenhagen.

\section{Geological setting and structural framework}

In its original concept the Wandel Sea Basin included the entire Carboniferous to Tertiary succession of eastern and central North Greenland (Dawes \& Soper, 1973). However, Håkansson \& Stemmerik (1989) recently concluded that the original name should only be maintained at an informal level. The latter authors outlined two major phases in the post-Devonian basin development, with Mesozoic strata confined entirely to the later, strike-slip dominated phase (Håkansson \& Pedersen, 1982; Håkansson \& Stemmerik, 1989).

The Late Palaeozoic phase in the evolution of the Wandel Sea Basin is described elsewhere in this volume by Stemmerik \& Håkansson (1991). Following mid-Permian collapse of an extensive Late Palaeozoic carbonate platform, North Greenland was subjected to a series of strike-slip movements along, or associated with, the major fault zones bordering the stable craton to the north and the north-east (Håkansson \& Pedersen, 1982). In the central part of the Wandel Sea Basin area 


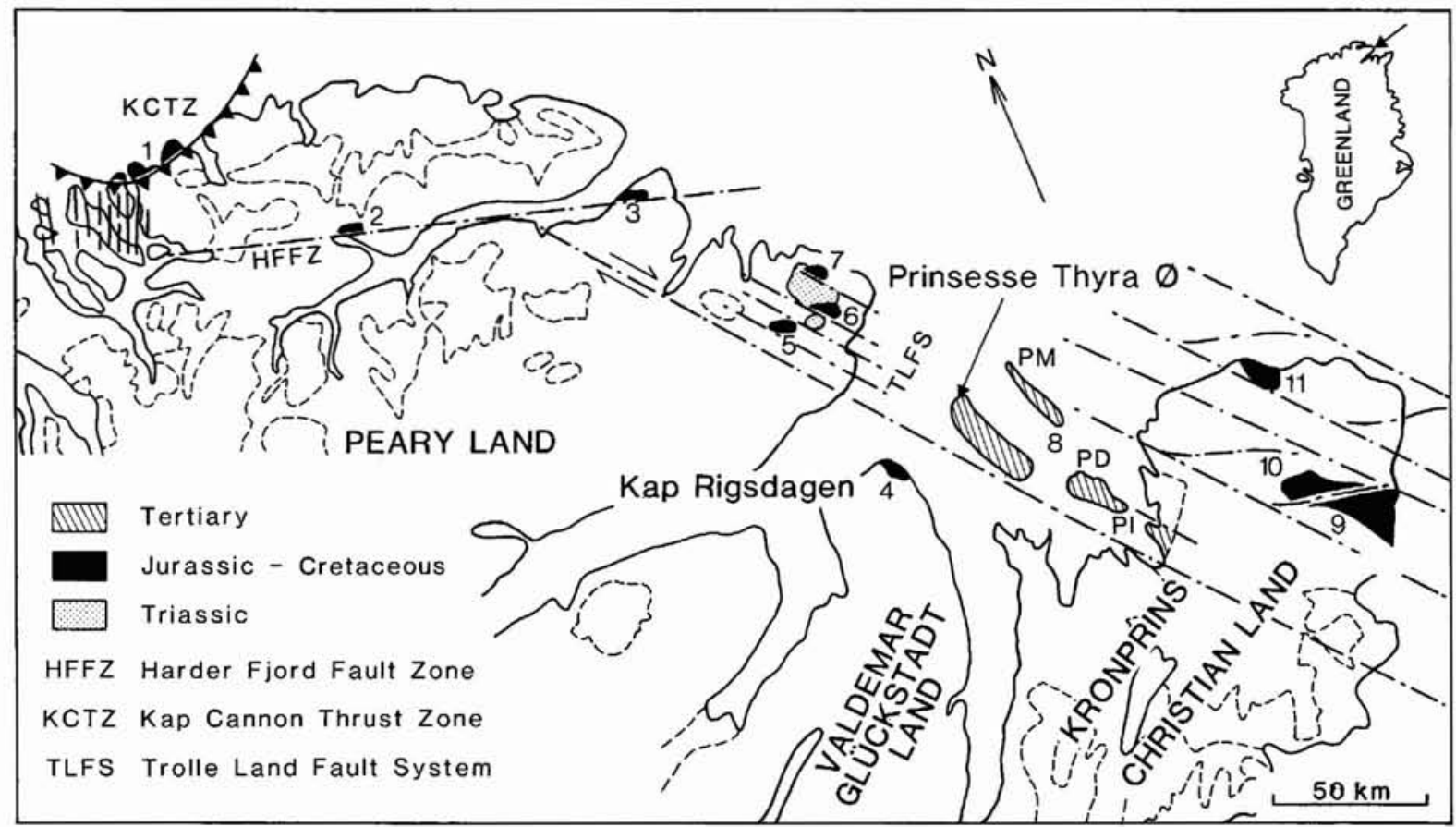

Fig. 1. Map of the main structural lineaments and sediment distribution of the Mesozoic and Cenozoic in the Wandel Sea Basin area. 1, Kap Washington basin; 2, Frigg Fjord basin; 3, Depotbugt basin; 4, Lower Cretaceous at Kap Rigsdagen; 5, 6, Upper Jurassic - Lower Cretaceous; 7, Triassic strata and Herlufsholm Strand basin; 8, Upper Paleocene; 9, Upper Jurassic - Lower Cretaceous; 10, Kilen basin; 11, Nakkehoved basin. Note the dyke swarm in association with the Kap Washington basin. PM, Prinsesse Margrethe $\emptyset$; PD, Prinsesse Dagmar $\emptyset$; PI, Prinsesse Ingeborg Halvø.

a system of largely parallel faults dissected the former platform in a NW-SE trending system (Fig. 1), which may extend across the present shelf and relate directly to the developing Spitzbergen Fracture Zone (cf. Håkansson \& Stemmerik, 1989, Fig. 2). In the on-shore part of central and eastern North Greenland this development found its climax in the Wandel Hav Strike-Slip Mobile Belt (Håkansson \& Pedersen, 1982), possibly as an immediate precursor of actual continent separation when Europe and Greenland finally started to drift apart early in the Tertiary (Birkelund \& Håkansson, 1983).

\section{The Ingeborg Event}

Throughout the Mesozoic Era central and eastern North Greenland were affected repeatedly by strike-slip dominated fault movements in the NW-SE trending Trolle Land Fault System (Fig. 1). An early series of movements which may be concentrated to the early part of the Jurassic has been termed the Ingeborg Event (Pedersen, 1988). In this phase of the history of the Wandel Hav Strike-Slip Mobile Belt, the sense of movement was most likely left-lateral. In eastern Peary Land in particular, differential block movements during this period resulted in an erosional level varying by more than $1 \mathrm{~km}$ between neighbouring fault blocks. In terms of basin development the Ingeborg Event had its most profound effect in a further subdivision of the Greenland part of the North Greenland - Svalbard basin. Hence, marine conditions were established in two largely independent areas of deposition (one sub-basin in eastern Peary Land and one in north-eastern Kronprins Christian Land) following the Late Jurassic transgression (Håkansson \& Stemmerik, 1989).

\section{The Kilen Event and the Kronprins Christian Land Orogeny}

Late Cretaceous geology in North Greenland was controlled by a complex series of events which together characterise the culmination of right-lateral displacement in the Wandel Hav Strike-Slip Mobile Belt (Håkansson \& Pedersen, 1982). To a large extent the structural elements are inherited from previous strike-slip phases and thus include broad scale rejuvenation of both the Trolle Land Fault System and the Harder Fjord 


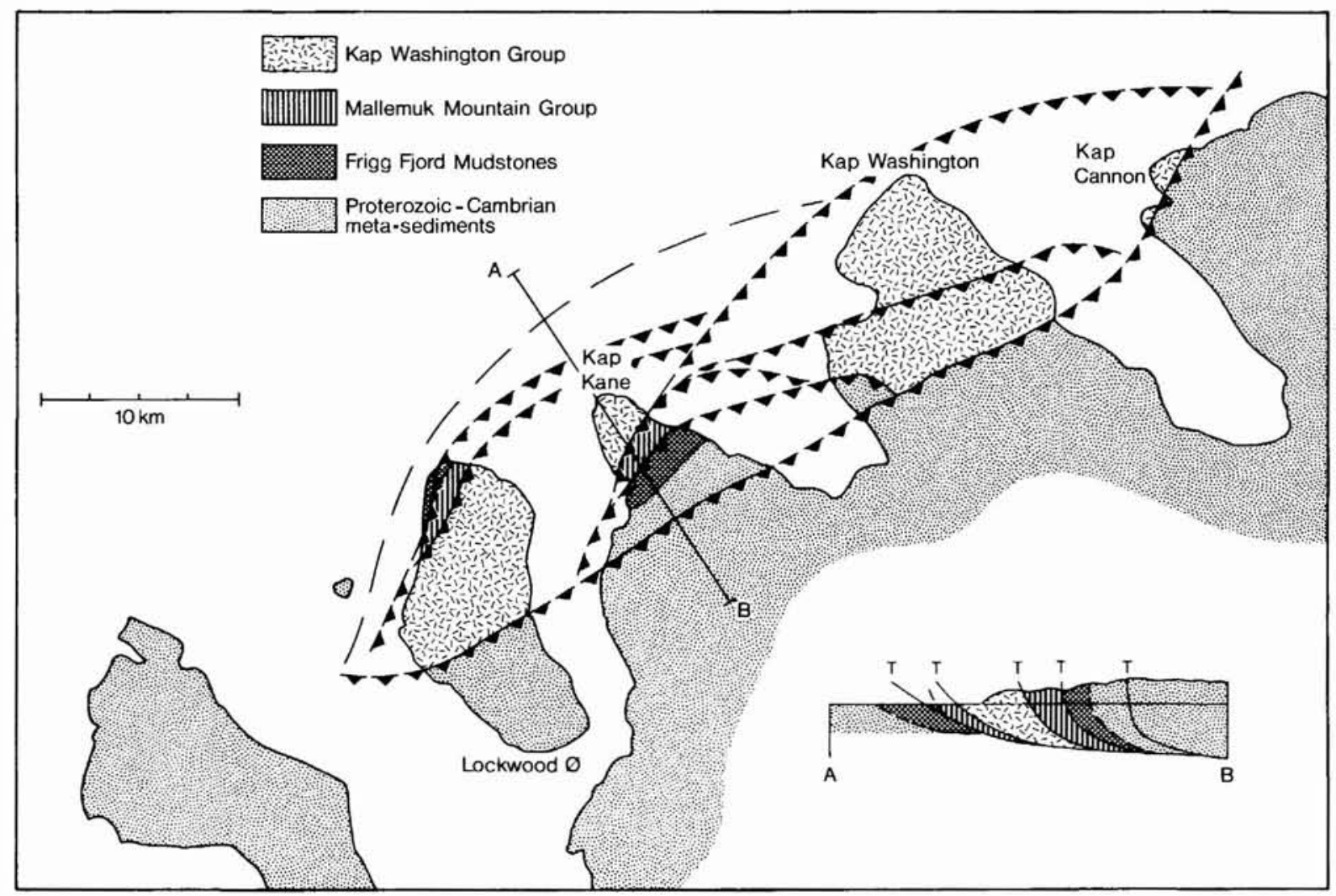

Fig. 2. The Kap Cannon Thrust zone and the Kap Washington basin, north-west Peary Land (after Håkansson \& Pedersen, 1982).

Fault Zone (Fig. 1). The intensity and style of deformation, however, change markedly in these later events.

The dominant extensional feature is the development of at least six local pull-apart basins across central and eastern North Greenland, with infill ranging from extrusive volcanics in the extreme western part of the mobile belt to continental clastic and fully marine clastic sediments in the remaining areas. This extensional phase has been termed the Kilen Event by Pedersen (1988). Regardless of depositional differences, all basins are characterised by a very limited areal extent, high rates of accumulation, rapid infill, and immature clastic constituents. In north-western Peary Land extensional forces are further expressed in the formation of a dense N-S striking dyke swarm (Fig. 1; Håkansson \& Pedersen, 1982; Birkelund \& Håkansson, 1983; Håkansson \& Stemmerik, 1984).

Compressional elements are similarly recorded all along the mobile belt and have been referred to the Kronprins Christian Land Orogeny by Pedersen (1988). The dominant style of deformation varies, however, in accordance with the direction of the pre-existing structural elements. Thus, in the Trolle Land Fault System, deformation consisted of reverse movements along the rejuvenated system of steep, NW-SE trending faults defining the zone, with associated E-W oriented domal folding and thrusting being conspicuous in several areas (Håkansson \& Pedersen, 1982; Pedersen, 1988; Håkansson et al., in press). Local, low grade shear-related metamorphism in Kronprins Christian Land is probably related to this orogeny (Håkansson et al., 1981b, 1989). Compression in the E-W trending Harder Fjord Fault Zone, on the other hand, is expressed almost exclusively in terms of reverse faulting and thrusting, with little folding and no appreciable strike-slip elements. In the Kap Cannon Thrust Zone, on the north coast of Peary Land, compression is expressed as a series of lobate, listric thrusts indicating an overall sense of displacement towards the north-west. The thrust pattern seems to indicate repeated episodes of deformation in addition to the initial pull-apart basin formation (Fig. 2; Håkansson \& Pedersen, 1982).

The final compressional phase everywhere post-dates the extension responsible for the formation of the pullapart basins. However, no convincing structural evidence for post-Cretaceous compression has yet been 
found anywhere in eastern North Greenland (Håkansson, 1988).

\section{Continental separation}

Following the major compressional events terminating activity within the Wandel Hav Strike-Slip Mobile Belt, the eastern part of North Greenland has apparently been subjected to only tensional events which can be more or less directly associated with the final separation of the American and European continents. Dating of most of these events, however, has so far not been possible due to the almost complete lack of deposits younger than Palaeocene.

\section{Depositional history}

The interaction of the three main structural events of the Wandel Hav Strike-Slip Mobile Belt accounts for the apparent paradox that Mesozoic and Cenozoic rocks are not only distributed in a patchy, mosaic pattern far more complex than the distribution of the underlying Upper Palaeozoic rocks, but also - in much of the area they are considerably more deformed than the Upper Palaeozoic strata. As a result, the preserved remnants of many units have a very limited areal extent (Fig. 3). Furthermore, the precision attained in dating Mesozoic and Cenozoic strata varies tremendously, with the result that it is difficult to accomplish detailed palaeogeographic reconstructions for most of the post-Palaeozoic period.

A formal lithostratigraphy has been proposed for only part of the sequence (Håkansson, 1979).

\section{Triassic clastic shelf sequences}

Due to tectonically controlled, differential erosion subsequent to the Ingeborg Event, Triassic strata of the Wandel Sea Basin are only preserved in a limited area in eastern Peary Land (Figs 1, 3; locality 7), where up to $1000 \mathrm{~m}$ of Triassic sediments rest with slight angular unconformity on Upper Permian rocks (Håkansson \& Pedersen, 1982). The sequence is almost exclusively clastic and, following a basal, reddish, pebble conglomerate, it comprises two major coarsening upwards sequences, referred to the Parish Bjerg (Fig. 4) and Dun-

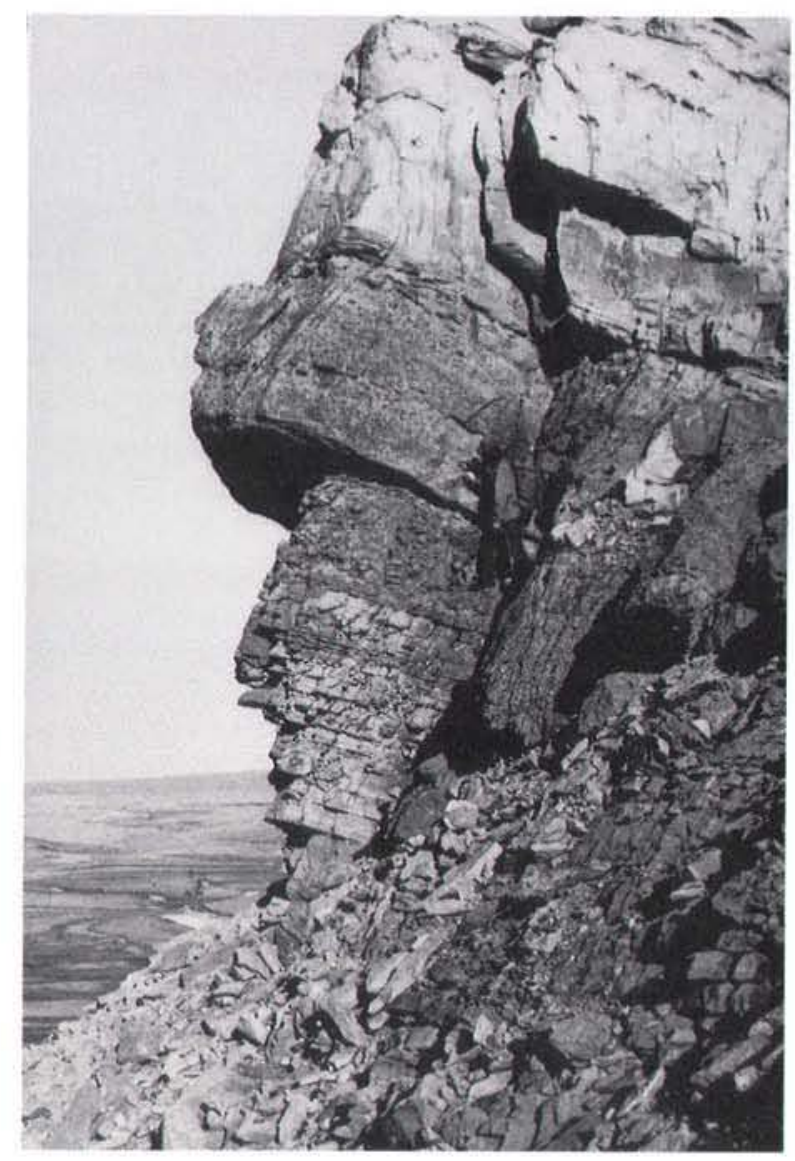

Fig. 4. Parish Bjerg Formation; upper sandy part with wedge of pebble conglomerate next to figure (centre), east Peary Land.

ken Formations (Fig. 5). The two formations are largely similar in composition, both being dominated by recessive, dark heteroliths giving way to an upper, more prominent unit largely composed of well sorted, fine grained sand. Comminuted carbonaceous detritus of probable terrigenous origin is common throughout most of the sequence but abundant trace fossils, as well as limited occurrences of body fossils, indicate a fully marine origin for the entire Triassic sequence. Each of the two coarsening upwards cycles reflects a major transgressive-regressive pulse with an initial deeper water phase shallowing abruptly due to coastal progradation.

In spite of the slightly angular relation between the Permian Midnatfjeld Formation and the Parish Bjerg

Fig. 3. Stratigraphy, thickness and depositional pattern of the Mesozoic and Cenozoic strata in the Wandel Sea Basin. Encircled numbers refer to localities in Fig. 1. KWG, Kap Washington Group; HSF, Herlufsholm Strand Formation; TøF, Thyra $\emptyset$ Formation; LÅF, Ladegårdsåen Formation; DF, Dunken Formation; NF, Nakkehoved Formation. 


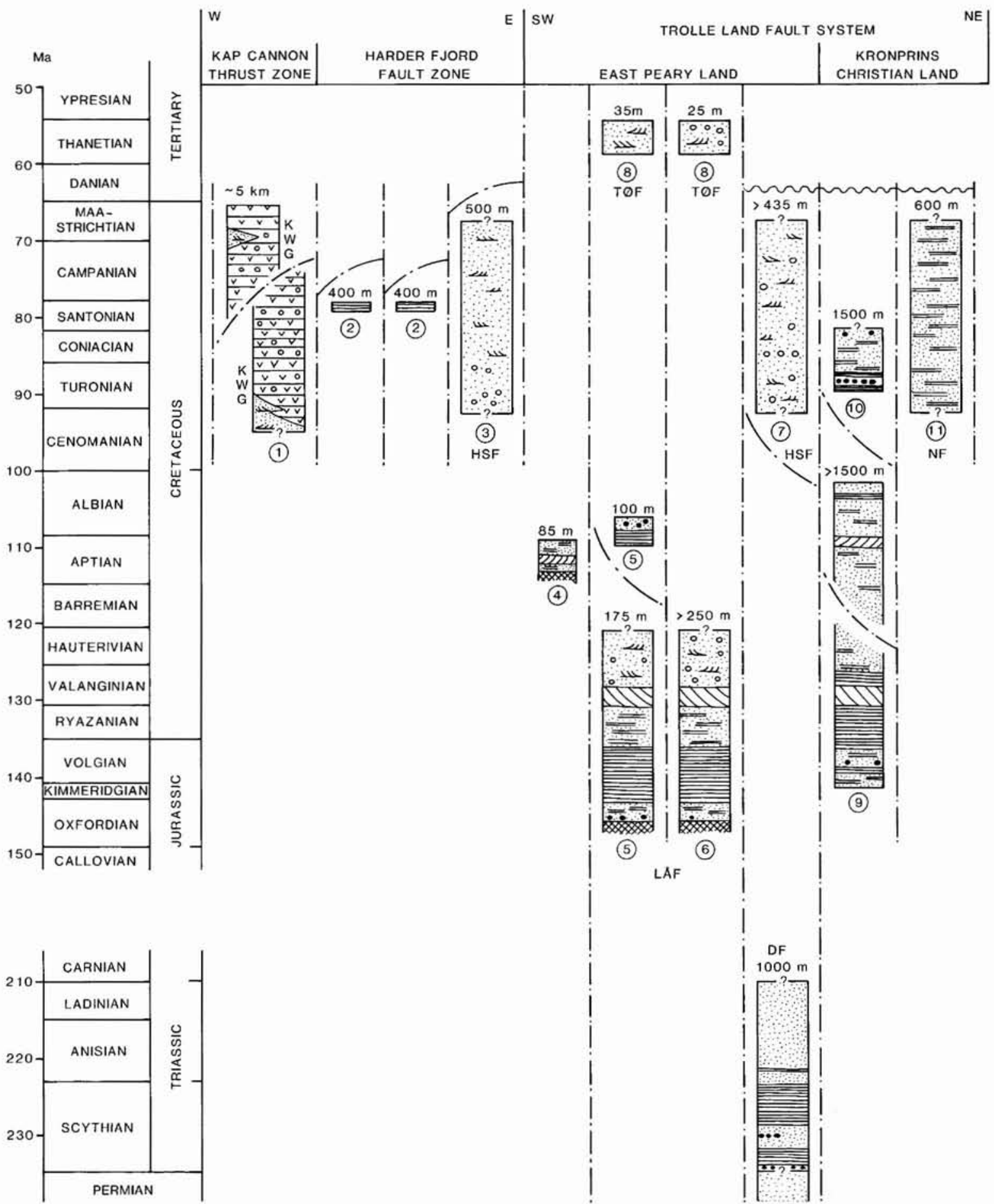

(7)

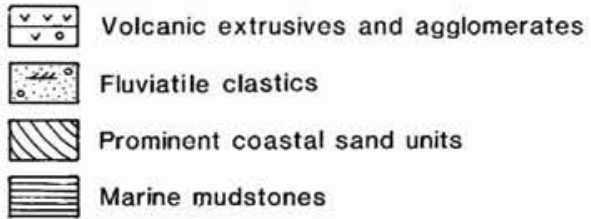

Marine sandy mudstones

Marine sands

$\because \bullet$ Marine conglomerates

Palaeozoic basement 


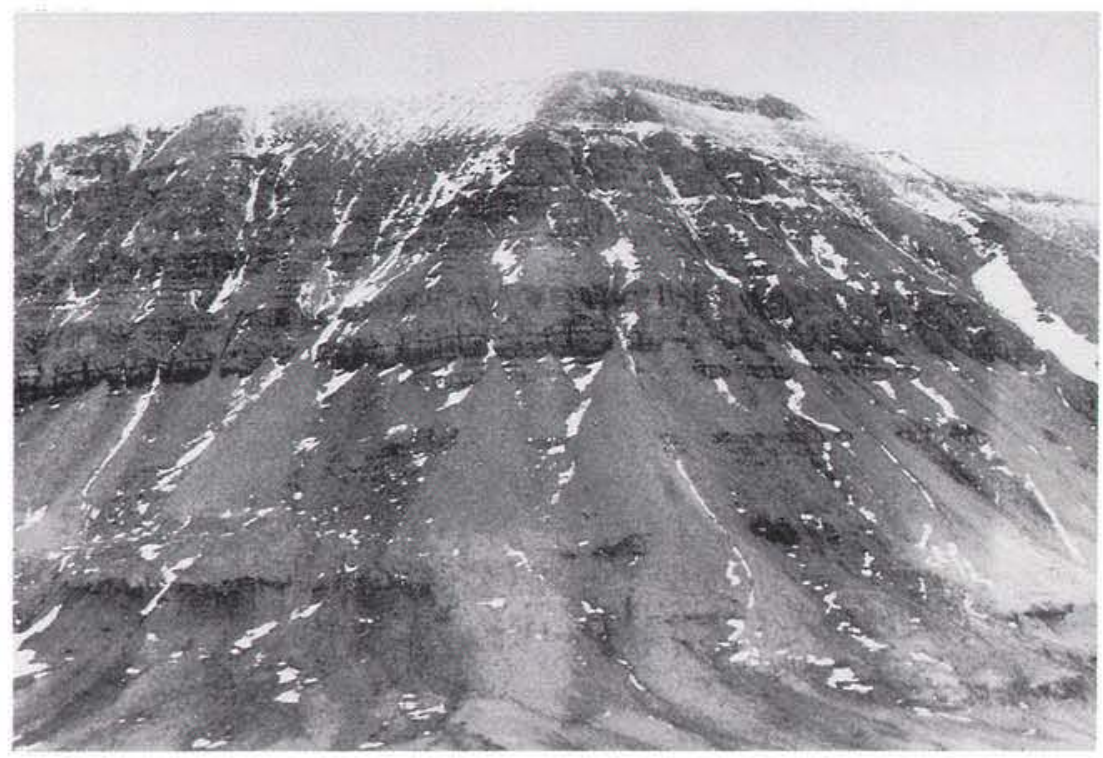

Fig. 5. Dunken Formation; the type profile Dunken is characterised by recessive shales in the lower part and prominent sandstone towards the top (height of cliff c. $600 \mathrm{~m}$ ). East Peary Land.

Formation, the Triassic depositional regime can be considered as a continuation of the pattern established in the northern part of the Wandel Sea Basin area in the mid-Permian tectonic event (i.e. in the North Greenland - Svalbard Basin; cf. Håkansson \& Stemmerik, 1989; Stemmerik \& Håkansson, 1991). The overall sedimentary pattern appears unrelated to the faults of the Trolle Land Fault System which now form the boundary of the Triassic sediments, and deposition during this period undoubtedly took place over a wider subsidence area. However, when compared to the depositional pattern and basin configuration in Svalbard (Steel \& Worsley, 1984), it is evident that the North Greenland Triassic constitutes a fully separate entity. Thus, even the very limited occurrence of Triassic strata in North Greenland provides evidence for the continuation of the platform break-up initiated in the Middle Permian.

Only part of the Triassic succession in North Greenland has so far been adequately dated. Palynomorph assemblages from the Parish Bjerg Formation are comparable to European floras of Early Triassic age, while Håkansson (1979), on the basis of the presence of a few euomphalid gastropods, suggested that the Parish Bjerg Formation may span the Permo-Triassic boundary. In the lower half of the Dunken Formation macrofossils indicate the presence of Scythian to Anisian strata (Kummel, 1953; Håkansson \& Heinberg, 1977; Håkansson, 1979). The upper part of the Dunken Formation has produced only non-diagnostic ichthyosaur remains. However, in view of the apparent continuity of sedimentation, deposition of the entire formation is considered to have been completed well within the Triassic period (Håkansson \& Stemmerik, 1984).

\section{Late Jurassic - Early Cretaceous sedimentation}

Strata referable to the later part of the Triassic and most of the Jurassic are missing in North Greenland. Deposition was restored in a major Late Jurassic transgression, evidence of which has been recognised in two distinct sub-basins in eastern Peary Land and Kronprins Christian Land (Fig. 3; localities 5, 6, 9). Apart from differences in depositional evolution, the sub-basins show differences in faunal and microfloral composition (Hảkansson et al., 1981a; Birkelund \& Håkansson, 1983). However, the overall pattern in the evolution of the depositional environments in both sub-basins shows sufficient similarity to allow an account of the sedimentation to be grouped under stratigraphic rather than regional headings. Thus a Late Jurassic - Early Cretaceous (Valanginian) marine interval is extensively documented in both eastern Peary Land and in Kronprins Christian Land, whereas strata recording a subsequent Aptian-Albian marine interval are now largely absent in eastern Peary Land.

Oxfordian-Valanginian transgressive/regressive pulse. The earliest post-Triassic strata in the Wandel Sea Basin area are recorded from eastern Peary Land where more than $250 \mathrm{~m}$ of sandstone, soft sands and shale referred to the Ladegărdsăen Formation unconformably overlie a complex mosaic of Silurian, Carboniferous and Permian sediments (Fig. 3; localities 5, 6; Hăkansson, 1979). Following a Middle Oxfordian transgression, marine fine grained sediments accumulated in a generally tranquil environment which apparently prevailed through the Kimmeridgian and Volgian Stages. 
Through the Rhyazanian a gradual change towards higher energy, more shallow water environments took place, culminating in an episode of coastal progradation in the Early Valanginian (Hăkansson et al., 1981a, 1981b; Hákansson \& Stemmerik, 1984). The lower, marine part of the Ladegårdsảen Formation has been dated with some precision in an integrated ammonite-Buchiadinoflagellate study (Hảkansson et al., 1981a), whereas the remaining non-marine parts so far have revealed no age indications.

The Kronprins Christian Land sub-basin exposed at Kilen (Fig. 3; locality 9) apparently also experienced a Late Jurassic transgression, but here the base of the approximately $900 \mathrm{~m}$ thick sequence is not known; the oldest unit exposed contains an ammonite fauna of Early Kimmeridgian age (Hăkansson et al., in press). In the Kimmeridgian-Valanginian part of the sequence, accumulation mostly took place in a muddy, barred, coastal environment and did not attain more open marine, offshore conditions until the Early Valanginian (Hákansson et al., 1981b; Birkelund \& Hăkansson, 1983). Subsequent to this, coarse, high energy coastal sands were deposited, concluding the first transgressive/ regressive pulse. However, in strong contrast to the development in the eastern Peary Land sub-basin, continental strata are absent at Kilen, where an additional transgressive/regressive pulse is documented. In this, a $550 \mathrm{~m}$ thick sequence of off-shore shelf mud contains gradually increasing proportions of partly hummocky bedded sand layers (Fig. 6). Unfortunately this interval has not produced any age diagnostic fossils.

Late Early Cretaceous transgression. Deposits from a late Early Cretaceous transgressive episode are almost exclusively preserved at Kilen in Kronprins Christian Land, where at least $650 \mathrm{~m}$ of mainly fine grained shelf clastics are present in a fault block distinct from the sequence discussed above (Fig. 3; locality 9; Håkansson et al., in press). As a result of the rather severe Late Cretaceous tectonic disturbance within the Wandel Hav Strike-Slip Mobile Belt actual thicknesses are difficult to ascertain, and relations to both older and younger strata have yet to be established. Preliminary investigations of the sparse fauna and microflora from this part of the sequence have revealed the presence of both Aptian and Albian strata. Most of the sequence accu-

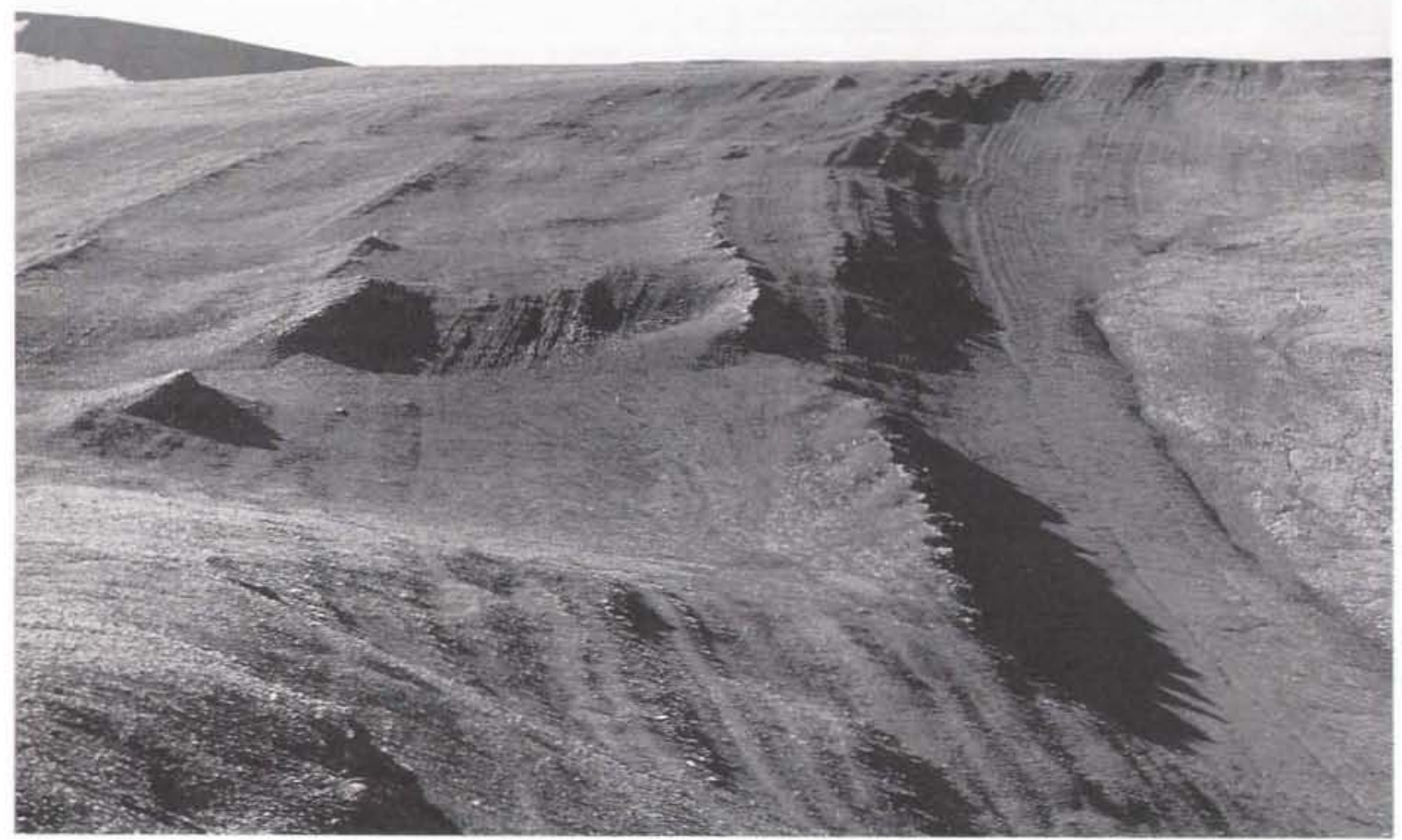

Fig. 6. Lower Cretaceous outcrops in the inner part of Kilen. The lower c. $200 \mathrm{~m}$ of the undated, post-Valanginian sequence showing the gradual increase of sandstone units in the offshore shelf mudstone is visible. Kronprins Christian Land. 
mulated in outer shelf environments with predominantly mud and fine sand facies (Håkansson et al., in press).

Two very limited occurrences may represent the remnants of a parallel transgressive development in the eastern Peary Land sub-basin. At Kap Rigsdagen in Valdemar Glückstadt Land (Fig. 1) an isolated sequence of marginally marine to lagoonal clastic deposits has yielded microfloras indicating an Aptian age for most of the $85 \mathrm{~m}$ of strata preserved (Fig. 3; locality 4; Håkansson et al., 1981b). In east Peary Land (Fig. 3; locality 5) a minute fault block exposing approximately $100 \mathrm{~m}$ of black mudstone capped by thin sandstones and shell conglomerates may be a somewhat younger open marine equivalent to the sequence at Kap Rigsdagen; the mudstone contains microfloras of Aptian age while ammonites of Early Albian age abound in the top conglomerate (Håkansson et al., 1981b; Rolle, 1981; Birkelund \& Håkansson, 1983).

\section{Late Cretaceous pull-apart basin formation}

Upper Cretaceous strata are distributed throughout the Wandel Sea Basin area, but their actual areal extent is very limited. Six distinct local pull-apart basins have been recognised along the on-shore part of the Wandel Hav Strike-Slip Mobile Belt (Fig. 3; localities 1-3, 7, 10, $11)$; suggestions concerning the presence of similar basins off-shore (Birkelund \& Håkansson, 1983) remain speculative in the lack of geophysical investigations. Of the six local basins, only the Herlufsholm Strand and Depotbugt basins show a similar depositional development, and so far no basins have been shown to have developed simultaneously. Based on the rather scanty stratigraphic evidence available, Birkelund \& Håkansson (1983) pointed out that the infill along the strike-slip belt is progressively younger towards the north-west. The apparently short duration of at least the well dated basins and the considerable thicknesses and immature nature of the sediments in all basins, suggest high rates of accumulation. Sediments in all these Late Cretaceous basins have experienced considerable organic degradation, and only occasionally have organic walled microfossils been preserved.

The westernmost two basins contain the only evidence of magmatic activity recorded in association with Wandel Sea Basin strata. One basin is almost entirely volcanic (Fig. 3; locality 1) and one is cut by postdeformational dykes (Fig. 3; locality 2). This magmatic activity is probably directly related to the N-S oriented dyke swarm in the western part of northern Peary Land (Fig. 1; Håkansson \& Pedersen, 1982).
Marine clastic deposits of the Kilen, Nakkehoved and Frigg Fjord basins. At Kilen, in Kronprins Christian Land, an at least $1500 \mathrm{~m}$ thick marine clastic sequence accumulated in the early part of the Late Cretaceous, exhibiting an overall shallowing development (Fig. 3; locality 10; Håkansson et al., in press). The initial deposit is a dark, organic-rich somewhat sandy mud with a depth-dependent, overall cyclicity in grain size composition, repeatedly interrupted by the influx of redeposited glauconitic and sideritic, largely bioclastic conglomerates suggesting fairly deep water environments. The proportion of sandy, shallow water sediments increases progressively, reflecting the gradual infill of the basin, but coarse clastic sediments only occur in significant proportions in the uppermost part of the sequence. Occasional macroscopic plant remains are present in the higher parts, but apparently the entire sequence was deposited in a marine environment (Håkansson et al., 1981b).

Following preliminary faunal investigations, including both the ammonites and the inoceramids, it appears that the lower half of the sequence was deposited during Middle Turonian to Early Coniacian times (Håkansson et al., 1981b; Birkelund \& Håkansson, 1983; Håkansson et al., in press). However, the upper part has so far not yielded age diagnostic fossils. The relation to an underlying, but undated marine sequence is not fully established.

The Late Cretaceous sequence at Kilen was strongly deformed into a series of domal folds and thrusts during the compressional regime of the Kronprins Christian Land Orogeny which everywhere terminated activity in the Wandel Hav Strike-Slip Mobile Belt (Håkansson \& Pedersen, 1982; Håkansson et al., in press).

In the nearby nunataks around Nakkehoved on the north coast of Kronprins Christian Land (Fig. 1), Upper Cretaceous sediments of a quite different nature are exposed (Fig. 3; locality 11). Here the Nakkehoved Formation comprises more than $600 \mathrm{~m}$ of monotonous, dark grey, fine-grained arkoses and quartz-sandstones deposited in a tranquil marine environment. The low diversity fauna comprises a variety of bivalves in addition to rare, thin tubular trace-fossils indicating only a general Late Cretaceous age (Håkansson et al., 1981b; Birkelund \& Håkansson, 1983). The sediments of the Nakkehoved Formation have been subjected to a shorttermed intense increase in heat flow. Neomorphic envelopes around feldspar grains in addition to a complete matrix recrystallisation indicate that the rock-suite locally has been subjected to temperatures well into the low greenschist range (Håkansson et al., 1981b; Håkansson \& Pedersen, 1982). However, in spite of this 
Fig. 7. Channel sands in the lower part of the Herlufsholm Strand Formation in the Depotbugt basin, central Peary Land (Fig. 1, locality 3).

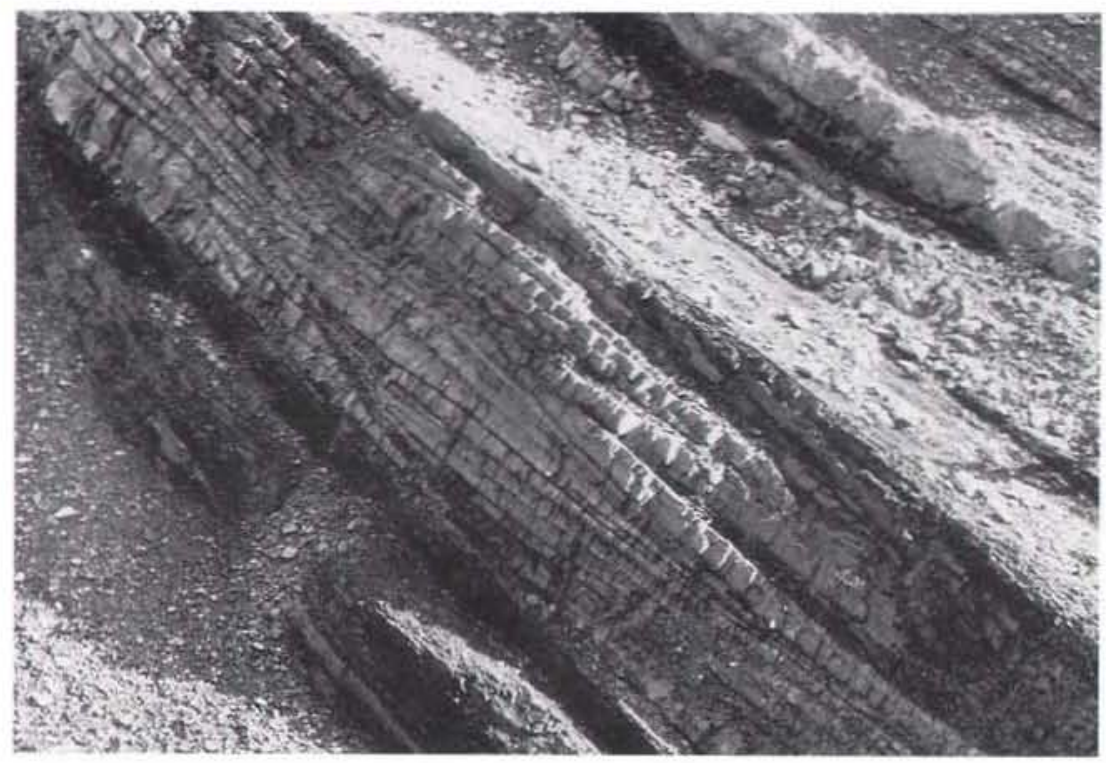

unusual thermal overprint, the sequence of the Nakkehoved Formation is only very gently disturbed.

Around the head of Frigg Fjord (Figs 1, 3; locality 2) some $400 \mathrm{~m}$ of dark marine sandy mudstone have been preserved as near vertical wedges in the large-scale tectonic mélange developed in this segment of the Harder Fjord Fault Zone. The sequence contains a well preserved, low diversity inoceramid fauna characteristic of the Late Santonian (Hãkansson et al., 1981b).

Fluviatile clastic deposits of the Herlufsholm Strand and Depotbugt basins. Two sequences dominated by fluvia- tile sandstone and carbonaceous shale are located in close association with the Harder Fjord Fault Zone (Fig. 1; locality 3) and the Trolle Land Fault System (Figs 1, 3; locality 7) in Peary Land. They have both been referred to the Herlufsholm Strand Formation (Hảkansson et al., 1981b). Outcrops are bounded by faults or thrusts, and strata in the Herlufsholm Strand basin are moderately folded. Both sequences are dominated by interbedded facies of immature sand and mud with abundant carbonaceous detritus (Fig. 7) and with subordinate conglomerates. Beds of true coal have not been found, but particularly in the Herlufsholm Strand

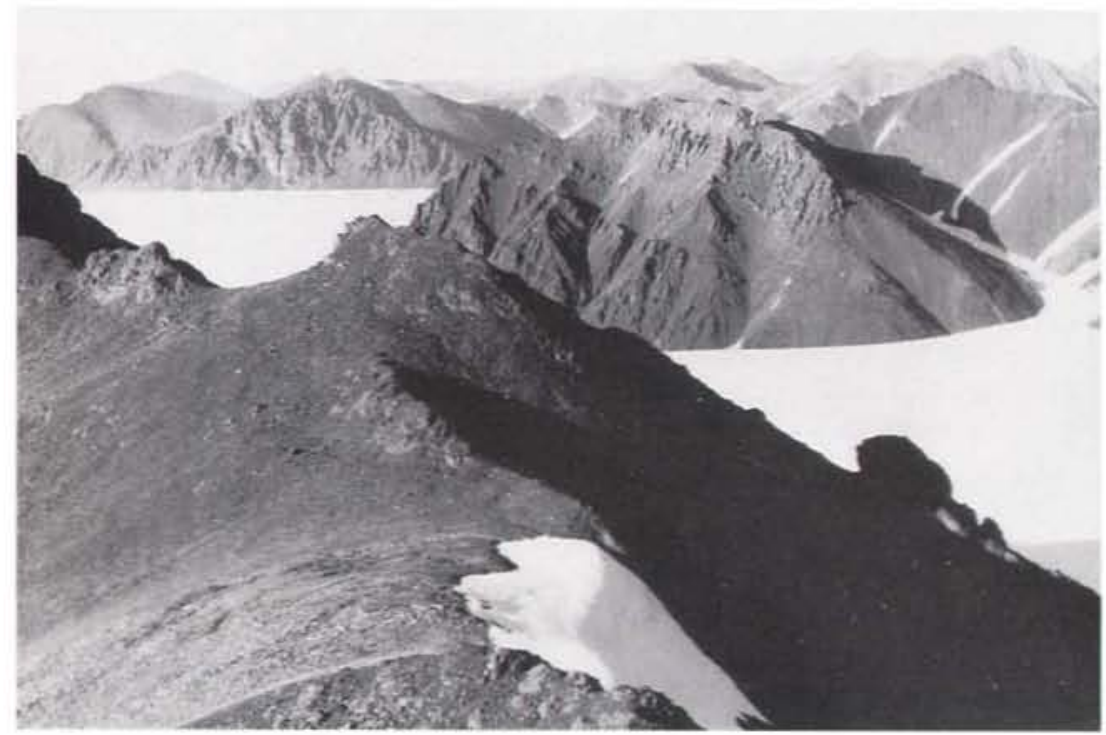

Fig. 8. Volcanic strata - mainly extrusives - from the lower part of the Kap Washington Group. Lockwood $\emptyset$, north-west Peary Land. 


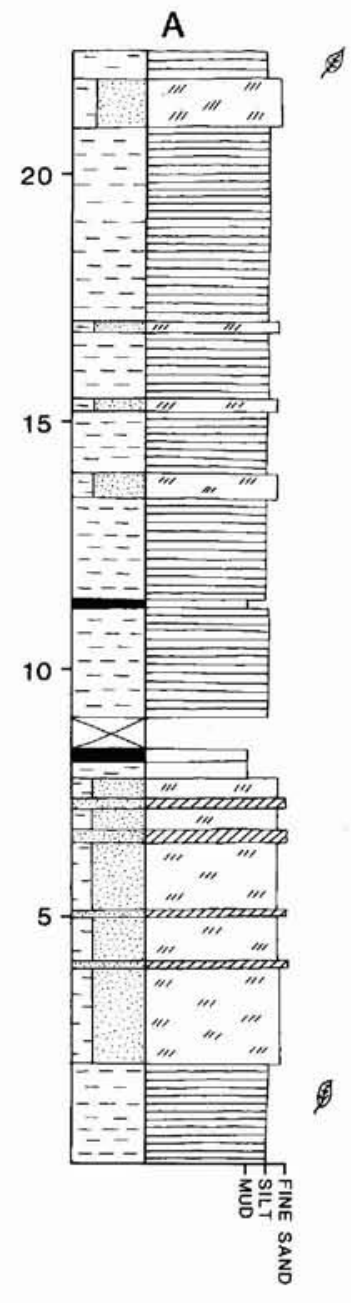

Lithology

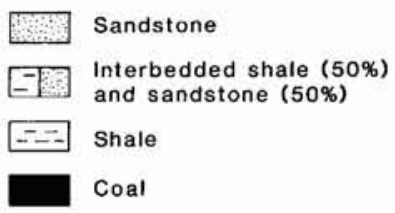

Structure

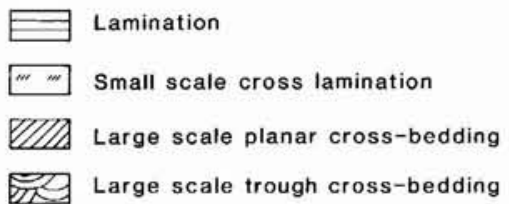

Fig. 9. Sediment logs of the Thyra $\varnothing$ Formation. A, B, Prinsesse Thyra $\emptyset$; C, southern Prinsesse Ingeborg Halvø.
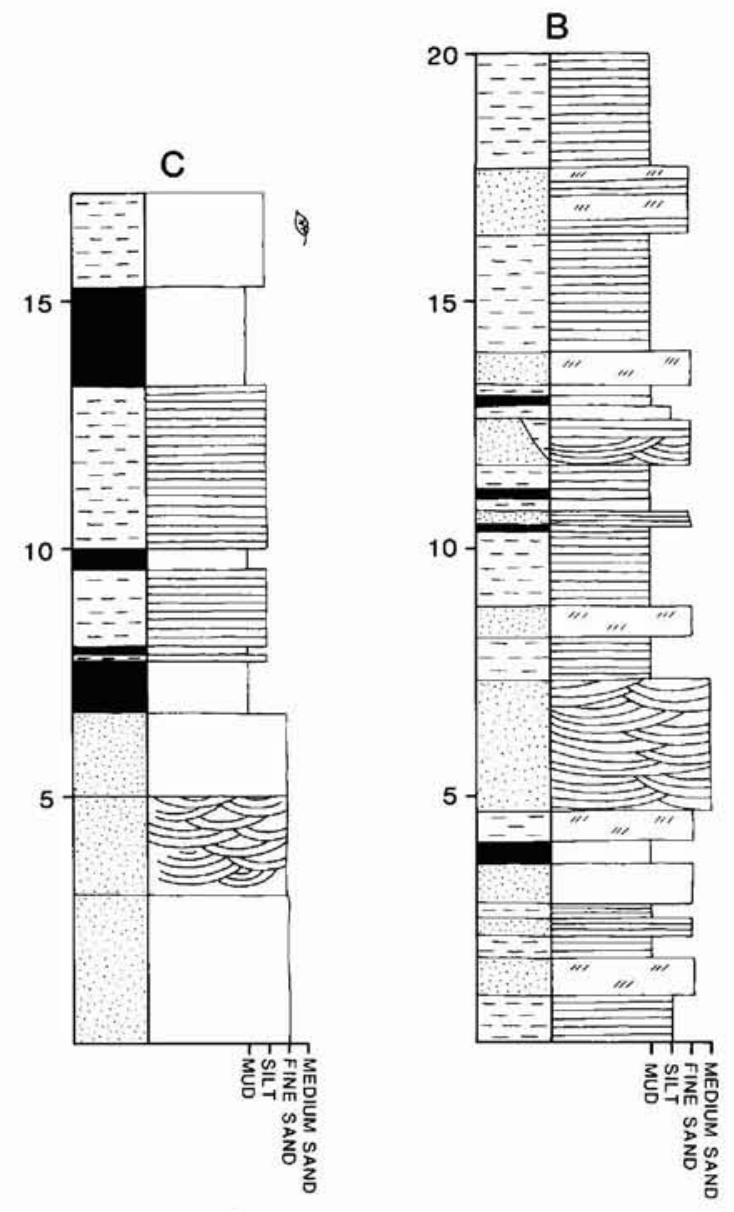

basin, highly carbonaceous shales packed with plant imprints are abundant. Coarse-grained arkosic beds are also conspicuous in this basin. No age diagnostic fossils have been found from either sequence and the age cannot be ascertained beyond the original Late Cretaceous to Early Tertiary estimate given by Troelsen (1950) for the Herlufsholm Strand sequence. However, the deformation and thermal history suggest a probable Late Cretaceous age (Håkansson \& Pedersen, 1982; Birkelund \& Håkansson, 1983).
Continental volcanics of the Kap Washington basin. The Kap Washington basin (Fig. 3; locality 1; Fig. 8) is the centre of volcanic activity during the development of the Wandel Hav Strike-Slip Mobile Belt and contains at least $5 \mathrm{~km}$ of various extrusive volcanic rocks and sediments (Brown \& Parsons, 1981); these accumulated in a narrow basin (Fig. 2; Håkansson \& Pedersen, 1982). Details of the sediments and the depositional environments are not available. The volcanic suite includes rhyolitic lavas and pyroclastic flows, trachytic and basal- 
tic lavas, as well as various tuffs, agglomerates and breccias, all of a peralkaline provenance (Brown \& Parsons, 1981; Soper et al., 1982). The age of the volcanic activity in the Kap Washington basin has been disputed, but it seems that accumulation took place in the Late Cretaceous, most likely during the interval from the Campanian to the Maastrichtian/Danian boundary (see discussion by Batten et al., 1981; Håkansson \& Pedersen, 1982; Soper et al., 1982; Birkelund \& Håkansson, 1983; Håkansson \& Stemmerik, 1984).

\section{Early Tertiary fluviatile sedimentation}

Sediments included in the early Tertiary Thyra $\varnothing$ Formation are restricted to the islands of Prinsesse Thyra $\varnothing$, Prinsesse Dagmar $\varnothing$, Prinsesse Margrethe $\varnothing$, and the southern part of the peninsula Prinsesse Ingeborg Halvø in the central parts of the Wandel Sea Basin area (Fig. 1; Håkansson et al., 1981b). The sediments are unaffected by compressional tectonism related to the Mesozoic strike-slip movements and therefore place an upward age limit on the Wandel Hav Strike-Slip Mobile Belt. It is suggested that they are of (Late?) Palaeocene age based on an abundant, but poorly preserved macroflora (Greenarctic Consortium in Dawes, 1976; A. Boyd, E. Håkansson \& L. Stemmerik, unpublished information) and a single diagnostic dinoflagellate specimen (Håkansson \& Pedersen, 1982).

The Thyra $\emptyset$ Formation is up to $50 \mathrm{~m}$ thick in outcrop but neither the base nor the depositional top are exposed. The sequence is dominated by interbedded finegrained sand and laminated silt with abundant coal seams particularly on Prinsesse Ingeborg Halvø (Figs 9, 10). Coarser sand and conglomerates are less prominent with the exception of a single isolated outcrop of con- glomerate with poorly rounded to subangular blocks on Prinsesse Margrethe $\varnothing$ farthest to the north-east.

Deposition apparently took place in the distal part of a broad flood plain. Increase in the proportion of laterally widespread coal seams and silt towards the south and west may imply that drainage was in this direction and that the more distally situated areas were dominated by swamps and lakes.

\section{Concluding remarks}

Late Palaeozoic to Early Cenozoic sedimentation in North Greenland has been referred to collectively as the Wandel Sea Basin, but it is now apparent that the dynamic history encompassed within this concept involves the development of a succession of superimposed and partly unrelated basins. The complexity of this history relates directly to long-lived activity along a number of fundamental tectonic lineaments which intersected in the Wandel Sea Basin area.

While Late Palaeozoic sedimentation may have taken place largely in a simple tensional regime with differential graben development, as described elsewhere in this volume (Stemmerik \& Håkansson, 1991), Mesozoic deposition in North Greenland was controlled by the mounting forces in a strike-slip belt which culminated in actual separation between North America/Greenland and Europe/Svalbard early in the Tertiary. Thus, most of the Mesozoic sedimentation took place in direct response to the dynamic evolution of the intra-cratonic Wandel Hav Strike-Slip Mobile Belt, with the dominantly shallow marine to continental clastic deposits accumulating in at least three generations of gradually smaller basins.

Activity in the mobile belt ceased subsequent to its
Fig. 10. Medium grained sandstone overlain by interbedded silt and coal (dark stripes), Thyra $\varnothing$ Formation (Fig. 9C).

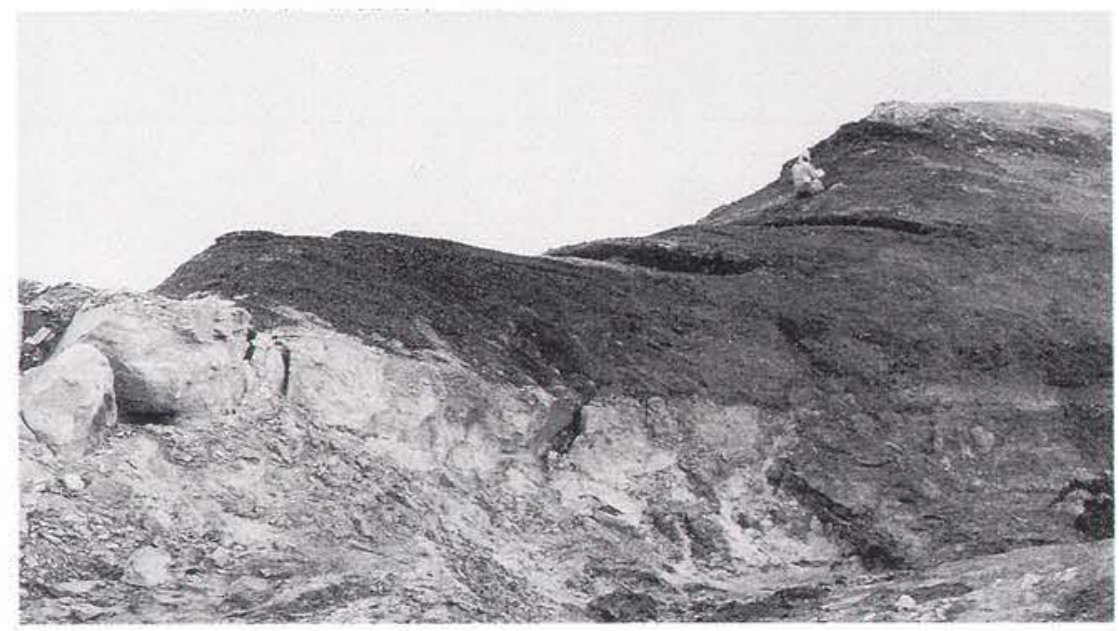


compressional climax, close to the Cretaceous-Tertiary boundary, and subsequent Palaeogene sedimentation in North Greenland took place entirely in a passive margin setting with tensional forces dominating.

Acknowledgements. Field work in 1976, 1978 and 1980 was made possible by the Geological Survey of Greenland while expeditions in 1985 and 1988 were financially supported by grants to E. H. from the Carlsberg Foundation. Jakob Lautrup, Jette Halskov, Bente Thomas, Nina Turner and Else Møller-Hansen are thanked for technical assistance in the preparation of the manuscript.

\section{References}

Batten, D. J., Brown, P. E., Dawes, P. R., Higgins, A. K., Koch, B. E., Parsons, I. \& Soper, N. J. 1981: Peralkaline volcanicity on the Eurasia Basin margin. Nature 294, 150152.

Birkelund, T. \& Håkansson, E. 1983: The Cretaceous of North Greenland - a stratigraphic and biogeographical analysis. Zitteliana 10, 7-25.

Brown, P. E. \& Parsons, I. 1981: The Kap Washington Group volcanics. Rapp. Grønlands geol. Unders. 106, 65-68.

Dawes, P. R. 1976: Precambrian to Tertiary of northern Greenland. In Escher, A. \& Watt, W. S. (ed.) Geology of Greenland, 249-303. Copenhagen: Geol. Surv. Greenland.

Hảkansson, E. 1979: Carboniferous to Tertiary development of the Wandel Sea Basin, eastern North Greenland. Rapp. Grønlands geol. Unders. 88, 73-83.

Håkansson, E. 1988: Did Tertiary compressional tectonics affect North Greenland? Summary of the evidence. Rapp. Norsk Polarinst. 46, 101-104.

Håkansson, E. \& Heinberg, C. 1977: Reconnaissance work in the Triassic of the Wandel Sea Basin, Peary Land, eastern North Greenland. Rapp. Gronlands geol. Unders. 85, 11-15.

Håkansson, E. \& Pedersen, S. A. S. 1982: Late Paleozoic to Tertiary tectonic evolution of the continental margin in North Greenland. In Embry, A. F. \& Balkwill, H. R. (ed.) Arctic geology and geophysics. Mem. Can. Soc. Petrol. Geol. 8, 331-348.

Håkansson, E. \& Stemmerik, L. 1984: Wandel Sea Basin - The North Greenland equivalent to Svalbard and the Barents Shelf. In Spencer A. M. et al. (ed.) Petroleum geology of the North European margin, 97-107. London: Graham \& Trotman for the Norwegian Petroleum Society.
Håkansson, E. \& Stemmerik, L. 1989: Wandel Sea Basin - A new synthesis of the late Paleozoic to Tertiary accumulation in North Greenland. Geology 17, 683-686.

Håkansson, E., Birkelund, T., Piasecki, S. \& Zakharov, V. 1981a: Jurassic-Cretaceous boundary strata of the extreme arctic (Peary Land, North Greenland). Bull. geol. Soc. Denmark 30, 11-42.

Håkansson, E., Heinberg, C. \& Stemmerik, L. 1981b: The Wandel Sea Basin from Holm Land to Lockwood $\varnothing$, eastern North Greenland. Rapp. Grønlands geol. Unders. 106, $47-63$.

Håkansson, E., Madsen, L. \& Pedersen, S. A. S. 1989: Geological investigations of Prinsesse Ingeborg Halvø, eastern North Greenland. Rapp. Grønlands geol. Unders. 145, 113118.

Håkansson, E., Birkelund, T., Heinberg, C., Hjort, C., Mølgaard, P. \& Pedersen, S. A. S. in press: The Kilen Expedition 1985 - an account of the geological and biological results. Submitted to Bull. geol. Soc. Denmark.

Kummel, B. 1953: Middle Triassic ammonites from Peary Land. Meddr Grønland 127(1), 21 pp.

Nielsen, E. 1941: Remarks on the map and the geology of Kronprins Christians Land. Meddr Grønland 126(2), 35 pp.

Pedersen, S. A. S. 1988: Model of structural events in the Late Mesozoic platform break up between Greenland and Svalbard. Rapp. Norsk Polarinst. 46, 99-100.

Rolle, F. 1981: Hydrocarbon source rock sampling in Peary Land 1980. Rapp. Grønlands geol. Unders. 106, 99-103.

Soper, N. J., Dawes, P. R. \& Higgins, A. K. 1982: CretaceousTertiary magmatic and tectonic events in North Greenland and the history of adjacent ocean basins. In Dawes, P. R. \& Kerr, J. W. (ed.) Nares Strait and the drift of Greenland: a conflict in plate tectonics. Meddr Gronland Geosci. 8, 205220.

Steel, R. J. \& Worsley, D. 1984: Svalbard's post-Caledonian strata - an atlas of sedimentational patterns and palaeogeographic evolution. In Spencer, A. M. et al. (ed.) Petroleum geology of the North European margin, 109-135. London: Graham \& Trotman Ltd. for the Norwegian Petroleum Society.

Stemmerik, L. \& Håkansson, E. 1991: Carboniferous and Permian history of the Wandel Sea Basin, North Greenland. Bull. Grønlands geol. Unders. 160 (this volume).

Troelsen, J. C. 1950: Geology. In Winther, P. C. et al. (ed.) A preliminary account of the Danish Peary Land Expedition, 1948-49. Arctic 3, 6-8. 